\title{
Corporate Social Responsibility: A Call For Multidisciplinary Inquiry
}

Rajiv Kashyap, (E-mail:kashyapr@wpunj.edu), William Paterson University

Raza Mir, (E-mail: mirr@wpunj.edu), William Paterson University

Ali Mir, (E-mail: mira@wpunj.edu) William Paterson University

\begin{abstract}
Corporate Social Responsibility (CSR) is one of the most important and pressing issues confronting business executives these days. Despite widespread attention, there is little agreement about what constitutes CSR, or why companies should pursue social objectives, or what effects this has on firm performance. We trace the evolution of the CSR concept in various business disciplines and synopsize interrelated constructs and themes. The picture that emerges suggests a multidimensional construct worthy of multidisciplinary attention.
\end{abstract}

\section{Introduction}

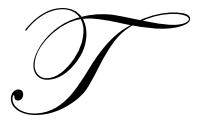

he overwhelming magnitude of recent corporate scandals has evoked a wave of soul searching among practitioners and academics. Driven by a quest to understand this remarkable decline in ethical conduct, an abundance of new research is being conducted (e.g., see forthcoming special issue on social responsibility in European Journal of Marketing in 2004, special sessions on social responsibility in Academy of Management Proceedings 2003). While most agree that social responsibility is a strong business imperative, there is little agreement about what it constitutes or how it should be incorporated. The problem lies in the disconnected silos of knowledge being concurrently developed and replicated in various business disciplines. Add to this evolving social standards and cultural differences superimposed on a global business landscape, and it is easy to see why the problem may appear intractable.

As a first step, one must explore the evolution of the corporate social responsibility concept. This historical trace identifies similarities and differences in themes and constructs among research streams. We hope that this will provide researchers with opportunities to enrich the discourse on corporate social responsibility. Another outcome of this evolutionary trace is the insight into the multidimensional nature of the CSR construct. We discuss ensuing problems and offer potential solutions. Our goal is to emphasize the importance of a multidisciplinary research agenda that utilizes multiple methods and multiple criteria.

\section{Evolution of Corporate Social Responsibility Concept}

The following discussion traces the evolution of the corporate social responsibility concept with regard to three questions (see Table 1):

1) What is corporate social responsibility?

2) Why should firms pursue social responsibility objectives?

3) How does it affect firm performance? 
Table 1. Evolution of the Corporate Social Responsibility Concept

\begin{tabular}{|c|c|c|}
\hline Corporate Social Responsibility Content & Motivations for CSR & $\begin{array}{c}\text { Effects of CSR on Firm } \\
\text { Performance }\end{array}$ \\
\hline $\begin{array}{l}\text { Attempts to define CSR } \\
\text { "Businessmen... must follow those lines of } \\
\text { action which are desirable in terms of } \\
\text { objectives and values of our society." } \\
\text { Bowen (1953) }\end{array}$ & $\begin{array}{l}\text { Socially responsible decisions can } \\
\text { have long term benefits } \\
\text { Davis (1960) }\end{array}$ & $\begin{array}{l}\text { Not possible to gauge economic } \\
\text { impacts of socially responsible actions } \\
\text { in most cases. } \\
\text { Manne and Wallich (1972) }\end{array}$ \\
\hline $\begin{array}{l}\text { Broadening of scope of CSR to include: } \\
\text { Consideration of employee and community } \\
\text { welfare and educational and political needs } \\
\text { of society. McGuire (1963) } \\
\text { Service to improve the quality of human } \\
\text { life. } \\
\text { Committee for Economic Development } \\
\text { (1971). }\end{array}$ & $\begin{array}{l}\text { Firms need to balance multiple } \\
\text { interests to ensure achievement of } \\
\text { multiple goals and long-run profit } \\
\text { maximization } \\
\text { Johnson (1971) }\end{array}$ & $\begin{array}{l}\text { Lexicographic view of social } \\
\text { responsibility: } \\
\text { Firms pay attention to social issues } \\
\text { only after meeting profitability goals. } \\
\text { Johnson (1971) }\end{array}$ \\
\hline $\begin{array}{l}\text { Acknowledgment of managerial role in } \\
\text { discharging CSR: } \\
\text { Quality of managerial response to changing } \\
\text { societal expectations is explicitly } \\
\text { mentioned. } \\
\text { Committee for Economic Development } \\
\text { (1971). } \\
\text { Businesses must not spoil society and } \\
\text { provide solutions through voluntary } \\
\text { assumption of obligations. } \\
\text { Manne and Wallich (1972) }\end{array}$ & $\begin{array}{l}\text { Iron Law of Responsibility: } \\
\text { Businesses must behave responsibly } \\
\text { or lose the power and legitimacy } \\
\text { granted by society. } \\
\text { Davis (1973) }\end{array}$ & $\begin{array}{l}\text { Theory of slack resources states that } \\
\text { firms that have resources to spare } \\
\text { outperform those that don't in terms of } \\
\text { social performance. } \\
\text { Waddock and Graves (1997) }\end{array}$ \\
\hline $\begin{array}{l}\text { Delineation of CSR and Actionable Models: } \\
\text { CSR encompasses economic, legal, ethical, } \\
\text { and discretionary expectations of society. } \\
\text { Carroll (1979) } \\
\text { Corporate Social Performance (principles, } \\
\text { processes, and policies). } \\
\text { Wartick and Cochran (1985) } \\
\text { Corporate Social Performance Framework } \\
\text { Principles, Processes, Outcomes. } \\
\text { Wood (1991) }\end{array}$ & $\begin{array}{l}\text { Normative stakeholder theory: } \\
\text { Firms are moral agents due to } \\
\text { contractual obligations to satisfy } \\
\text { societal expectations. } \\
\text { Donaldson (1983) }\end{array}$ & $\begin{array}{l}\text { Social problems can be turned into } \\
\text { business opportunities to create wealth. } \\
\text { Drucker (1984) }\end{array}$ \\
\hline
\end{tabular}


Table 1 (continued)

\begin{tabular}{|c|c|c|}
\hline $\begin{array}{l}\text { Corporate Social Responsibility } \\
\text { Content }\end{array}$ & Motivations for CSR & Effects of CSR on Firm Performance \\
\hline $\begin{array}{l}\text { Delimiting the Scope of CSR and } \\
\text { Development of Complementary } \\
\text { Constructs } \\
\text { Stakeholder Theory } \\
\text { Businesses are responsible to those who } \\
\text { can affect or are affected by its } \\
\text { purposes. } \\
\text { Freeman (1984) } \\
\text { Enviropreneurial Marketing } \\
\text { Menon and Menon (1997) } \\
\text { Corporate Citizenship } \\
\text { Maignan, Ferrell, and Hult (1999) } \\
\text { Corporate Environmentalism } \\
\text { Bannerjee, Iyer, and Kashyap (2003) }\end{array}$ & $\begin{array}{l}\text { Instrumental stakeholder theory } \\
\text { Firms must satisfy stakeholders because } \\
\text { they are instrumental to achieving firm } \\
\text { objectives. } \\
\text { Freeman (1984) }\end{array}$ & $\begin{array}{l}\text { Environmentalism improves business } \\
\text { performance } \\
\text { Environmentally responsible firms can } \\
\text { garner competitive advantages through } \\
\text { cost reductions, differentiation potential, } \\
\text { and strategic direction. } \\
\text { Porter and van der Linde (1995); Hart } \\
\text { (1995) } \\
\text { Klassen and McLaughlin (1999); } \\
\text { Judge and Douglas (1998) }\end{array}$ \\
\hline $\begin{array}{l}\text { Corporate Sustainability } \\
\text { Corporate Sustainability demands } \\
\text { attention to economic, environmental, } \\
\text { and social issues. } \\
\text { van Marrewijk (2003) }\end{array}$ & $\begin{array}{l}\text { Sustainable Theory of Firm } \\
\text { Satisfying stakeholders is the sole } \\
\text { purpose and reason for a firm's } \\
\text { existence. } \\
\text { McWilliams and Siegel (1995); Stead } \\
\text { and Stead (2001) } \\
\text { Sustainable Value } \\
\text { Strategies that simultaneously drive } \\
\text { sustainable development and } \\
\text { shareholder value create sustainable } \\
\text { value. } \\
\text { Hart, Milstein, and Caggiano (2003) }\end{array}$ & $\begin{array}{l}\text { Sustainable Growth: } \\
\text { "a business approach that creates long- } \\
\text { term shareholder value by embracing } \\
\text { opportunities and managing risks } \\
\text { deriving from economic, environmental } \\
\text { and social developments." } \\
\text { Dow Jones Sustainability Index } 1999\end{array}$ \\
\hline
\end{tabular}

Bowen (1953 p.6), often regarded as a pioneering advocate of corporate social responsibility (Carroll 1999), suggested that CSR refers to "... the obligations of businessmen to pursue those policies, to make those decisions, or to follow those lines of action which are desirable in terms of the objectives and values of our society." Further attempts to elaborate the construct focused attention on firm obligations that extended beyond the economic and legal domains to include employee and community welfare, and the political and educational needs of society (McGuire 1963), thus giving rise to the modern concept of corporate citizenship (Maignan, Ferrell, and Hult 1999). This broadening of responsibilities was articulated by the Committee for Economic Development (1971), which saw CSR as the service of a wider range of human values to improve the quality of life. They also suggested that the future of business was dependent on the quality of managerial response to changing societal expectations. According to researchers at the time, CSR was distinguished by its long (as opposed to short) term managerial focus (Steiner 1971) and discretionary rather than mandated actions (Manne and Wallich 1972). CSR was comprised of two phases, first to not "spoil" society and second, to improve and provide solutions to societal problems through voluntary assumption of obligations and commitment. Carroll (1979 p. 500) summarized the discussion by offering the following definition: "Social responsibility of business encompasses the economic, legal, ethical, and discretionary expectations that society has of organizations at a given point in time." Note that economic and legal obligations refer to (clear-cut) mandated responsibilities while ethical and discretionary obligations refer to (not so clear-cut) societal expectations. This was followed by an attempt to broaden the CSR concept (Wartick and Cochran 1985) to one of corporate social performance that included three components: principles, processes, and policies. The most significant contribution for our purposes came from Wood (1991) who elaborated and connected these three interrelated themes. First, she explained why industries, firms, and managers should endeavor to engage in socially responsible behavior (principles of legitimacy, public responsibility, and managerial discretion). This was followed by an explanation of how socially responsible objectives might be formulated and achieved (processes of environmental assessment, stakeholder management, and issues management). Finally, a description of what 
outcomes or results (i.e., social impacts, programs, and policies) should be expected with respect to the CSR domains was provided. In an effort to validate its usefulness to skeptics, management researchers circumscribed the scope of CSR by developing stakeholder theory (Freeman 1984; Donaldson and Preston 1995). Stakeholder theory armed its protagonists with strategic arguments to favor those stakeholders that might affect long term success and survival. In a similar attempt to delineate the scope of corporate social and environmental responsibility and clarify its potential value, marketing researchers developed the constructs of corporate citizenship (Maignan, Ferrell, and Hult 1999), environpreneurial marketing (Menon and Menon 1997), and corporate environmentalism (Bannerjee, Iyer, and Kashyap 2003). This delimited view of CSR has much appeal since it provides a basis for firm strategy and aids accountability. More recently, an alternate perspective argues that the stakeholder approach be translated into a model of corporate sustainability (Marrewijk 2003), that demands managerial attention to economic, environmental, and social issues. This view is supported by a sustainable theory of the firm, and calls to support the creation of sustainable value.

Quite early in the CSR discussion, Davis (1960) attempted to justify socially responsible decision making by asserting the long term benefits of socially responsible decisions. Later, Johnson (1971) asserted that social responsibility was necessary since firms needed to balance multiple interests (e.g., stockholders, employees, suppliers, dealers, and local communities) to ensure the achievement of multiple goals and long-run profit maximization. Manne (1972) suggested that trying to gauge actual motives for business expenditures would be too difficult, since many business expenditures have multiple motives. In summary, these views held CSR as instrumental to the accomplishment of firm objectives such as profit maximization, long term success, and or survival. Another perspective (a.k.a. Iron Law of Responsibility) was offered by Davis (1973), who suggested that unless businesses behaved responsibly, they would lose the power and legitimacy granted by society. As this concept gained support, researchers began to argue for a normative approach to CSR (Donaldson 1983; Frederick and Weber 1987). They contended that firms were moral agents due to their contractual obligations to satisfy societal expectations and should therefore assume moral responsibilities (Donaldson 1983; Swanson 1999). In the mean time, the instrumental view continued to muster support through empirical inquiry (McGuire, Sundgren, \& Schneeweis, 1988; Berman, Wicks, and Kotha 1999). The debate over whether social responsibility arises due to normative or instrumental reasons has raged hard over the last decade (see for example the special issue on Stakeholder Theory in the Academy of Management Review 1999). Currently, the key word is sustainability. At one end, this lays the foundations for a new theory of the firm (Stead and Stead 2000) by asserting that firms provide stakeholders with a raison d'etre. At the other, it provides a logical argument for simultaneously pursuing sustainable development and shareholder value for the creation of sustainable value (Hart, Milstein, and Caggiano 2003).

Early themes in CSR conceptualization emphasized that corporate volunteerism was critical to the discharge of social responsibilities. Additionally, it was proposed that managers should accept that it would not be possible to gauge the economic impacts of socially responsible actions in most cases (Walton 1967). This view clearly saw CSR as being at best subservient to the economic interests of the firm. Taking this a step further, Manne and Wallich (1972) argued that in order for business expenditures to qualify as socially responsible, they must provide lower returns than an alternative investment. The dominant logic was that firms should accept the costs for discharging social responsibilities that might negatively impact or at best not affect the bottom line. This premise was later replaced by the lexicographic view of social responsibility (Johnson 1971), which suggested that firms paid attention to social responsibility issues only after they had met their profitability goals. Subsequently adapted as a theory of slack resources, this view is still offered as an explanation for variations in firm social performance (Waddock and Graves 1997). For a long time, social responsibility was viewed as a cost to the firm rather than a source of revenues. However, the emerging paradigm that views CSR and shareholder wealth as complementary goals is motivated by a different school of thought. This new business imperative owes its origin to Drucker (1984), who was the first to suggest that not only were social responsibility and profitability compatible, but also that social opportunities could be converted into business opportunities. He went on to propose that businesses should turn social problems into economic opportunities and benefits, and ultimately into wealth. Theoretical and empirical support for this view came initially from the literature on environmentalism, that is, research on how firms mange their relationships with the natural environment. For instance, Porter and van der Linde (1995) argued how stringent regulations could be turned into opportunities to improve firm efficiencies, while Hart (1995) explained competitive 
advantages accruing to environmentally responsible firms by adapting the resource based view of the firm. Research has shown that pollution prevention type (as opposed to end-of-pipe) technologies improved environmental and financial performance (Klassen and McLaughlin 1999), while incorporating environmental issues into the strategic planning process provided superior financial performance (Judge and Douglas 1998). The movement has gathered momentum in recent years and has evolved into the sustainable growth business model, which extends beyond environmental responsibility to encompass community and employee welfare, corporate philanthropy, and supplier / distributor partnerships. This is evidenced by a new corporate sustainability index (Dow Jones Sustainability Index 2000) designed to meet the needs of social investors. The DJSI identifies and monitors the performance of "innovative and future oriented firms" that achieve competitive advantage from environmental and social growth opportunities. In a similar vein, our thesis propagates and extends our understanding of how firms may satisfy stakeholders and simultaneously meet social and economic objectives.

In summary, we find that CSR is a multidimensional construct deserving of multidisciplinary attention. While such attention has been forthcoming lately, there is a problem in that parallel and overlapping themes and constructs are being simultaneously developed in various business disciplines. This has resulted in lack of clarity and differences in meanings assigned to constructs. It is necessary to clarify, integrate and coordinate CSR research for its proper advancement.

\section{Multidimensionality of the CSR concept}

In this section, we discuss the multidimensional nature of the CSR concept and offer potential solutions for addressing this problem. Multidimensionality is problematic for researchers as it necessitates the study of several domains and disciplines and must be considerate of multiple perspectives. In addition, it requires more comprehensive research design - a problem for most researchers already constrained by time and cost limitations. CSR multidimensionality arises from six different factors:

1. Diversity in the set of processes deemed to constitute a set of socially responsible firm behaviors: For instance, Wood (1991) points out that it is not a single process, rather a set of processes by which a firm's social performance can be judged. In her opinion, in order to evaluate a company's social performance, "researchers would examine the degree to which principles of social responsibility motivate actions taken on behalf of the company, the degree to which the firm makes use of socially responsive processes, the existence and nature of policies and programs designed to manage the firm's societal relationships, and the social impacts" (Wood 1991, p. 693).

2. Multiple stakeholders with differing, often conflicting interests: There is often conflict between competing stakeholder claims (Freeman and Gilbert 1988; Ryan 1990). Recent analyses of firms engaging in socially responsible behavior have shown interest in showcasing firms deemed responsible by one set of stakeholders and largely irresponsible by another. For instance, the Body Shop is often cited as the paragon of environmental friendliness. However, there are many who question the inherent worth of cosmetic products to society (Economist, May 24 2003)

3. Differences in corporate missions or values that motivate firms to engage in socially responsible activities: Differences in corporate missions and cultures with respect to CSR may be attributed to external environmental forces such as public opinion or regulatory pressures or internal drivers such as top management commitment or the need for competitive advantage (Bannerjee, Iyer and Kashyap 2003). Such differences in antecedent influences lead to wide variations in performance, making it harder for researchers to partial out the effects of socially responsible initiatives.

4. Variances in performance attributed to socially responsible behavior: A number of studies have shown significant differences in firm performance with regard to socially responsible initiatives (Balabanis, Phillips, and Lyall 1998; McWilliams and Siegel 2000; Stanwick and Stanwick 1998). Not all socially responsible behavior has the same effect on firm performance and such initiatives are often moderated (Aragon-Correa and Sharma 2003; Bannerjee, Iyer, and Kashyap 2003; Sen and Bhattacharya 1999) by a variety of firm (e.g., size, employee skills, brand reputation) and environmental characteristics (e.g., competitive intensity, industry type). Note that since stakeholder perceptions of firm motivations may moderate evaluations of social responsibility initiatives (Sen and Bhattacharya 2001; Aragon-Correa and 
Sharma 2003), such moderating factors must be carefully controlled during empirical investigation of the relationship between CSR and firm performance.

5. Subjectivity in judging what constitutes socially responsible behavior: The confluence of dynamic and evolving ethical standards, varying definitions of social responsibility due to cultural differences (Maignan and Ferrell 2003), and differences in industry practices and norms increase the degree of subjectivity about what is deemed socially responsible. Such subjectivity is further compounded by whether a short or long term perspective is adopted. In Votaw's words (1973 p.11), "To some it (CSR) conveys the idea of legal responsibility or liability; to others it means socially responsible behavior in an ethical sense; to still others, the meaning transmitted is that of "responsible for", in a causal mode; many simply equate it with charitable contribution." This has created problems for researchers trying to operationalize and empirically test models of corporate social responsibility (Clarkson 1995).

6. Multiple domains of CSR: In an early essay, Carroll (1979) proposed that corporate social responsibility consisted of four components relating to a firm's economic, legal, ethical, and discretionary obligations. While this was initially meant to distinguish between mandated and voluntary action, it later formed the basis for empirical inquiry into corporate social performance (Acar, Aupperle, and Lowy 2001). These multiple domains necessitate attention to several interrelated firm objectives and require psychometrically valid measures to capture the full dimensionality of the concept. Also, varying degrees of importance given to these domains by different stakeholders make assessment of CSR a difficult task.

\section{Methodological Implications and Conclusion}

The above discussion clearly underscores the need for a multidisciplinary inquiry of CSR. Next, we discuss the methodological implications of such multidimensionality and propose some solutions. The first step would involve establishing common definitions and standards for CSR and associated constructs. For this purpose, it may be useful to start with an assessment of stakeholder expectations and build up towards a collective definition of CSR. Agreement across disciplines regarding concepts and definitions is necessary for the purpose of establishing construct validity. In addition, this would help researchers develop nomological networks to differentiate CSR from associated constructs and assist in the evaluation of discriminant validity. Such agreement would also facilitate the development and use of common measures for CSR and associated constructs so that CSR performance can be reliably evaluated.

Second, the dynamism of the CSR concept highlights the need for new approaches and research designs. It necessitates longitudinal research designs to evaluate the progress of firms at various points in time. Within-industry studies would be useful for controlling the influence of context-specific norms and moderating factors. This would also enable researchers to deal with the issue of test-retest reliability. Triangulation is critical, not just of method, but also of concepts and findings. Multiple methods that simultaneously utilize perceptual and behavioral measures can help establish predictive validity. One key problem especially with self reported measures of motivation and values is social desirability bias. Developing indirect measures and triangulating studies with multiple methods would help alleviate this problem. Triangulation of results and key findings of studies would also help establish criterion validity.

In conclusion, we feel that there is an urgent need for collaborative and coordinated efforts to study CSR. We hope that such multidisciplinary research will herald a new age that is succeeded by multidisciplinary teaching and practice.

\section{References}

1. Acar William, Kenneth E. Aupperle, and Ronald M. Lowy (2001), "An Empirical Exploration of Measures of Social Responsibility Across the Spectrum of Organizational Types," The International Journal of Organizational Analysis, 9 (1), 26-57.

2. Aragon-Correa, J. Alberto and Sanjay Sharma (2003), “A Contingent Resource-Based View of Proactive Corporate Environmental Strategy," Academy of Management Review, 28 (1), 71-88. 
3. Balanabis, George, Hugh Phillips, and Jonathan Lyall (1998), "Corporate Social Responsibility and Economic Performance in the Top British Companies: Are They Linked?" European Business Review, 98 (1), 25-44.

4. Bannerjee, Bobby Subhabrata, Easwar S. Iyer, and Rajiv K. Kashyap (2003), "Corporate Environmentalism: Antecedents and Influence of Industry Type," Journal of Marketing, 61 (April), 106122.

5. Berman Shawn L., Andrew C Wicks, Suresh Kotha, and Thomas M Jones (1999), "Does Stakeholder Orientation Matter? The Relationship Between Stakeholder Management Models and Firm Financial Performance," Academy of Management Journal, 42 (October), 488-506.

6. Bowen, H. R. (1953). Social Responsibilities of the Businessman. New York: Harper and Row.

7. Carroll, Archie B. (1999), "Corporate Social Responsibility: Evolution of a Definitional Construct," Business and Society, 38 (September), 268-295.

8. _ _ (1979), “A Three Dimensional Conceptual Model of Corporate Social Performance," Academy of Management Review, 4, 497-505.

9. Clarkson, Max B E (1995), "A Stakeholder Framework for Analyzing and Evaluating Corporate Social Performance," Academy of Management Review, 20 (January), 92- 117.

10. Committee for Economic Development (1971). Social Responsibilities for Business Corporations. New York: Author.

11. Davis, Keith (1973). The Case For and Against Business Assumption of Social Responsibilities," Academy of Management Journal, 1, 312-322.

12. _ (1960), "Can Business Afford to Ignore Social Responsibilities?" California Management Review, 2 (Spring), $70-76$.

13. Donaldson, Thomas and Lee E; Preston, (1995), "The Stakeholder Theory of The Corporation: Concepts, Evidence, and Implications," Academy of Management Review, 20 (January), 65-91.

14. _ (1983), "Constructing a social contract for business," In T. Donaldson \& P. Werhane (Eds.), Ethical issues in business: 153-165. New York: Oxford University Press.

15. Drucker, Peter F. (1984), "A New Look at Corporate Social Responsibility," McKinsey Quarterly, 4 (Autumn), 17-28.

16. Dow Jones Sustainability Index (2000), http://www.sustainability-index.com, Accessed February 10, 2011.

17. Economist (May 24, 2003), "Pots of Promise," Special Report: The Beauty Business, 71-73.

18. Freeman, R. Edward. (1984). Strategic management: A stakeholder approach. Boston: Pitman.

19. _ _ and Daniel R. Gilbert (1988). Corporate strategy and the search for ethics. Englewood Cliffs, NJ: Prentice-Hall.

20. Frederick, W.C. and J. Weber (1987), "The Values of Corporate Managers and Their Critics," In W.C. Frederick \& L. E. Preston (Eds.). Research in Corporate Social Performance and Policy, 9, 131-152. Greenwich, CT: Jai Press.

21. Hart, Stuart L. (1995), "A Natural-resource-based View of the Firm," Academy of Management Review, 20 (October), 986-1014.

22. Johnson, H. L. (1971). Business in Contemporary Society: Framework and Issues. Belmont, CA: Wadsworth.

23. Judge Jr, William Q. and Thomas J. Douglas, (1998), "Performance Implications of Incorporating Natural Environmental Issues Into the Strategic Planning Process: An Empirical Assessment," Journal of Management Studies, 35 (March), 241-260.

24. Klassen, Robert D. and D. Clay Whybark (1999), "The Impact of Environmental Technologies on Manufacturing Performance," Academy of Management Journal, 42 (6), 599-615.

25. Maignan Isabelle and O C Ferrell (2003), "Nature of corporate responsibilities: Perspectives from American, French, and German consumers," Journal of Business Research; 56 (January), 55-67.

26. van Marrewijk, Marcel (2003), "Concepts And Definitions of CSR and Corporate Sustainability: Between Agency and Communion," Journal of Business Ethics, 44 (May), 95-105.

27. Menon, Ajay and Anil Menon (1997), "Enviroprenuerial Marketing Strategy: The Emergence of Corporate Environmentalism as Market Strategy," Journal of Marketing, 61 (January), 51-67.

28. McGuire, J. W. (1963). Business and Society. New York: McGraw-Hill. 
29. McGuire, J., Sundgren, A., and Schneeweiss, T. (1988) "Corporate Social Responsibility and Firm Financial Performance," Academy of Management Journal, 31 (4) 854-872.

30. McWilliams, Abagail and Donald Siegel (2001), "Corporate Social Responsibility: A Theory of the Firm Perspective," Academy of Management Review, 26, 117-127.

31. Maignan Isabelle, O. C. Ferrell and G. Thomas M. Hult (1999), "Corporate Citizenship: Cultural Antecedents and Business benefits," Journal of the Academy of Marketing Science," 27 (4), 455-469.

32. Manne, H.G. and H. C. Wallich (1972). The Modern Corporation and Social Responsibility. Washington D.C.: American Enterprise Institute for Public Policy Research.

33. McWilliams, Abigail and Donald Siegel (2000), "Corporate Social Responsibility and Financial Performance: Correlation or Misspecification?” Strategic Management Journal, 21 (May), 603-609.

34. Porter, Michael E., and Claas,van der Linde, "Green and Competitive: Ending the Stalemate," Harvard Business Review, 73 (September/October), 120-134.

35. Ryan, L. V. (1990), "The Evolution of Stakeholder Management: Challenges and Potential Conflicts," International Journal of Value-Based Management, 3(1), 105-119.

36. Sen, Sankar and C. B. Bhattacharya (2001), "Does Doing Good Always Lead to Doing Better? Consumer Reactions to Corporate Social Responsibility," Journal of Marketing Research, 38, (May), 225-243.

37. Stanwick, Peter A. and Sarah D. Stanwick (1998), "The Relationship Between Corporate Social Performance and Organizational Size, Financial Performance, and Environmental Performance: An Empirical Examination,” Journal of Business Ethics, 17 (2), 195-204.

38. Steiner, George A. (1971). Business and society. New York: Random House.

39. Stead, Jean Garner and Edward Stead (2000), "Eco-enterprise strategy: Standing for sustainability," Journal of Business Ethics, 24 (4), 313-319.

40. Swanson, Diane L (1999), "Toward an Integrative Theory of Business and Society: A Research Strategy for Corporate Social Performance," Academy of Management Review, 24 (July), 506-521.

41. Votaw, D. (1973), "Genius Becomes Rare," In D. Votaw \& S. P. Sethi (Eds.). The corporate dilemma: Traditional values versus contemporary problems: 11-45. Englewood Cliffs, NJ: Prentice Hall.

42. Waddock, Sandra A. and Samuel B Graves (1997), "The Corporate Social Performance-Financial Performance Link," Strategic Management Journal, 8 (April), 303-319.

43. Walton, C C. (1967). Corporate Social Responsibilities. Belmont, CA: Wadsworth.

44. Wartick, Steven L. and Philip L. Cochran (1985), "The Evolution of the Corporate Social Performance Model," Academy of Management Review, 10, 758-769.

45. Wood. Donna (1991), "Corporate Social Performance Revisited," Academy of Management Review, 16, 691-718. 